Article

\title{
German Citizens' Perception of Fattening Pig Husbandry-Evidence from a Mixed Methods Approach
}

\author{
Inken Christoph-Schulz * (D) and Anja-Karolina Rovers $\mathbb{D}$ \\ Thuenen Institute of Market Analysis, Bundesallee 63, D-38116 Braunschweig, Germany; \\ anja.rovers@thuenen.de \\ * Correspondence: inken.christoph@thuenen.de; Tel.: +49-531-5965325
}

Received: 30 June 2020; Accepted: 5 August 2020; Published: 7 August 2020

check for updates

\begin{abstract}
Pig production in Germany is experiencing an increasing discrepancy between social attitudes, wishes and the reality. To investigate the actual perception and knowledge of fattening pig husbandry by German citizens, a mixed methods approach was carried out. First, six focus group discussions were conducted. Content analysis showed that space availability, fresh air supply and flooring type are particularly relevant in citizens' perception, whereas surgical interventions on the animal are perceived less. Furthermore, preventive use of antibiotics is seen critically by the participants. Based on these results, an online survey with 399 respondents was conducted to quantify the results. Findings from the focus groups were confirmed: Lack of space as well as the perceived precautionary use of medication were seen most critically. Results are influenced by if respondents have visited a farm before, the dietary behavior and sex.
\end{abstract}

Keywords: fattening pig production; perception; mixed methods approach; focus group discussions; online survey; citizens

\section{Introduction}

Nowadays, livestock production systems are getting much public interest and concern in Western societies [1,2]. There has been an on-going discussion about how farm animals should be kept for several years [3] and ethical concerns about animals' husbandry are rising [4]. Public criticism about farm animal welfare is increasing [5], especially for intensive systems such as pig or poultry production [6]. In $2015,82 \%$ of questioned EU citizens stated, with respect to the current situation, that farm animal welfare should be enhanced [7]. In Germany, this figure had risen to 87\% of respondents in 2017 [8].

Farmers are mainly criticized by the society due to perceived bad living conditions for their animals, such as indoor breeding or high stocking density [9-11]. Public criticism of modern livestock production systems has different reasons: many citizens retrieve their perceptions regarding animal husbandry from picture books and biased media. Furthermore, there is a permanent shift in values concerning animals, their emotions and their rights as living beings [12]. These developments could also be driven by the on-going urbanization, modern ways of mass media communication or campaigns by non-governmental organizations (NGOs) $[13,14]$. Farmers cannot be indifferent to this social criticism as they might lose their license to produce by society and consequently their license to operate through politics [15].

With respect to pig production, consumers see possible outdoor access as crucial [10]. Daylight and air quality are further mentioned aspects [16]. Meuwissen et al. [17] presented 24 aspects of pig production to their respondents and showed that flooring type, medication (preventive, curative and growth-enhancing) and space per animal were more important than outdoor/indoor access or 
group/single stocking of pigs for not beforehand informed respondents of their survey. Surgical interventions including castration of male piglets, teeth grinding and tail docking was the least important factor of all. In a cross-national study, factors such as the going loose instead of being fixed for sows or short transportation times to slaughter are clearly more important than a castration of piglets using pain killers or local anesthesia [18].

This recent divergence between livestock production systems and social attitude is also true for Germany as one of the biggest livestock producing countries in the EU [10]. Regarding pig production, Germany is also one of the key players with a net yield of 5,348,000 $t$ pork and a self-sufficiency of $119 \%$ in 2018 [19]. However, the growing social criticism of agricultural livestock farming in Germany also has economic consequences for the sector: in 2017, meat and meat products were the most important product group in the German food industry, accounting for $23.7 \%$ of total sales [20], but consumption is tending to decline slightly: per capita, the consumption of pork in Germany fell between 2000 and 2019 from 54.7 to $47.3 \mathrm{~kg} / \mathrm{capita}$ [21] The segment of vegetarians and vegans in Germany has risen in the last years and is now $5 \%$ for vegetarians and $1 \%$ for vegans $[22,23]$.

According to the studies by $[9,11,24]$, for German citizens, the most important factor in pig production is space availability, although castration has been an actively debated topic in the past, and regulation regarding castration has changed due to societal pressure. The legal minimum requirements for space and floor conditions are perceived as critical points by the German society [10,25]. Outdoor access in pig production is seen as important for German pork consumers [20] and has a positive public image, even if respondents are informed about possible negative environmental effects [26]. In recent years, the fixing of sows has received particular criticism [27]. Furthermore, light and climate conditions [28] as well as opportunities and sources of engagement play a role in the social perception of pig farming [29]. In contrast, (anesthesia-free) piglet castration and other surgical interventions on pigs seem to be less relevant [25]. Furthermore, many German citizens realize a connection between a limited space availability and other similarly critical perceived attitudes of husbandry, such as the use of medication $[10,11,30]$.

A more comprehensive picture of the perception of pig production by the public is given in studies dealing with stimuli. Wildraut et al. [9] showed their participants video sequences from farms and considered that the available space is a major criterion of pig husbandry linked to animal welfare. They also concluded that the flooring type of the pig farm is of central importance for the test persons. Furthermore, outdoor access is considered as ideal by the respondents in their study. Busch et al. [31] presented students pictures from existing pig farms and found, among other things, that technical production differences, such as the flooring type, were hardly noticed by the respondents [31]. Furthermore, toys for the animals as sources of engagement were not recognized as such by the majority of the study participants. "Engagement and toys" was an even less important criterion for animal welfare of pork products compared with space availability, outdoor access, flooring type and materials for investigation and manipulation, including rooting [24].

The increased importance of animal welfare as a social issue is also reflected in the stated willingness to pay extra for products from better husbandry conditions [32,33]. In a survey of Dutch consumers, Mulder and Zomer [34] found that, among other things, outdoor access for broilers increases willingness to pay and Pouta et al. [35] stated that domestic products can induce consumers to pay more. It has also been shown that labels have an influential effect $[35,36]$. However, this willingness to pay a price premium does not refer to all consumers but to certain consumer segments [37-39]. According to Liljenstolpe [40], preferences for pork from farms with improved animal welfare are heterogeneous. Here, too, consumer segments have been identified that are willing to pay a higher price while other consumers are not willing to pay this premium. However, results should not be overestimated: Following a meta-analysis study, there is a small willingness-to-pay for animal welfare, e.g., based on animal type and region, but it is the lowest for pigs [41]. Regarding the situation in Germany for pork produced under higher animal welfare conditions, there are segments of consumers with little additional willingness-to-pay for such products compared to conventional ones: price 
premiums of approximately 30 cents were accepted for a pork article in the middle price segment (price increase of 9\%-13\%). If, on the other hand, the price premiums were significantly higher or even lower, demand for these products decreased [24].

In contrast, consumers with a meat-based diet seem to dislike thinking about animal husbandry conditions [42]. Besides the socio-cultural aspects such as animal welfare, other primary product aspects such as quality, health and safety play an (even more) important role for consumers, but younger people living in urban areas seem to pay more attention to animal welfare [43].

Against this background, a new perspective to this topic is presented by combining qualitative and quantitative research. The following research questions will be examined:

RQ1: What is the actual perception and knowledge of current fattening pig husbandry by German citizens?

RQ2: How do German citizens describe their criticism of recent fattening pig husbandry?

RQ3: What can be concluded against the background of the current public debate regarding animal husbandry?

The objective of this article is to present insights about the main points of criticism of citizens of farmers and political decision-makers.

\section{Materials and Methods}

\subsection{Mixed Methods Approach}

In this study, a mixed methods approach, combining qualitative focus group discussions with a following quantitative online survey with almost representative quotas for the German population, was applied and carried out. Both parts are described more in detail below.

According to [44], both qualitative and quantitative methods are combined in mixed method approaches with the aim of gaining a deeper understanding of the research topic. Especially if the subject matter is new, sequencing qualitative and quantitative methods will help to understand and identify the research topic in the first place and quantify the results in a next step [45]. The combination of both methods can contribute to evaluate a topic from different perspectives, and they can each make up for the weaknesses of the other method [46]. Thus, enhancement and illustration of the results from one method can be achieved by using the results of the other one. In this regard, focus group discussions have the advantage to give insights into the structure and processes of individual or collective opinions [47].

\subsection{Focus Group Discussions}

The aim of focus group discussions is to ascertain perceptions and opinions as well as deeper structures of consciousness [48]. The moderation of focus group discussions often uses a guideline with provided questions to lead the discussion process. All participants are asked and debate together. Single opinions do not have priority but reveal the participants' range of views. The interactions between the participants and their changes of view are of interest [49]. Focus group discussions as a qualitative research method are not representative, but their advantages are only a few repetitions and that the results occur in a dynamic process. Thus, in contrast to standardized quantitative surveys, unexpected issues outcrop [50].

In this study, six focus group discussions using an interview guideline were conducted in three German cities Oldenburg (Lower Saxony), Fulda (Hesse) and Halle/Saale (Saxony-Anhalt)—two at each location. The interview guideline was discussed several times with a group of colleagues who were not involved in this specific project in order to exclude biasing influences to the discussants. For selection, several criteria were appointed: The chosen cities were in different federal states, considering North, South as well as East and West Germany. The concentration of farms per region was also considered (referring to [51]), including various forms of animal husbandry (more intensive or more extensive) as well as differences in stocking densities per region. 
The discussions consisted of eight up to eleven participants who were acquired by a market research company using different criteria in order to achieve heterogeneous groups with different points of view. Regarding gender and age, previous studies indicate that older female respondents with a higher income are more likely to have production practice bans and limitations [52]. Therefore, each discussion round consisted of about one-half male and one-half female participants to avoid gender-specific answers; age (from 18 to 70 years old) and employment (at least 33\% employed) was also considered. Previous studies have shown a different willingness to consider with the topic animal husbandry between people consuming meat and meat products and people following a plant-based diet [42]. Therefore, the discussions also included one up to two persons who did not consume pork and have a vegetarian or vegan diet because of several reasons: e.g., today's conditions of livestock production, the image of meat as a "climate killer" or the taste could affect an individual's decision to consume or avoid animal products in their diet. Against this background, "citizens" instead of "consumers" were chosen for the focus group discussions. Due to the character of a qualitative study and its limitations, differences such as the participants' age or gender were not analyzed in more detail. Furthermore, discussants had no specific background in agriculture (no job in agriculture or surroundings, no study or qualification, no family background) or in market research. Depending on personal experiences, there were participants included who had already visited a farm (e.g., while purchasing food at a farm shop), watched a documentation about farming on TV or heard something about farming by word-of-mouth recommendation.

To obtain the citizens' personal perception, the discussions' exact topic was not mentioned beforehand. Hence, participants could not inform themselves and had to answer spontaneously. At the beginning, some discussion rules were presented to ensure that every participant could mention their opinion without being interrupted. Participants were informed that their personal perception was welcomed and that there were no wrong or right answers. During the discussions, more restrained participants were actively addressed, dominant ones were slowed down.

The discussion guideline started with two opening questions: "What's your perception of the recent fattening pig husbandry?" and "What do you think, how does the fattening pig feel itself in that kind of husbandry you talk about?". Both questions were used to discuss the participants' perceptions of actual pig husbandry with respect to housing design, animal health and animal well-being. Depending on a literature review, perception of outdoor access, farm design and flooring type, sources of engagement, space availability, surgical interventions and medication were discussed more in detail. In these cases, questions were kept as unspecific as possible to avoid any interviewer influence, for example: "What do you think, how do the floors in a pig farm look like?" or "What does a pig eat?". In case of surgical interventions, it was necessary to give at least some information before participants were able to discuss the topic during the focus groups. On the other hand, the topic of medication never had to be addressed by the moderator since it was raised in connection with other discussions points, e.g., feed. In addition, participants were asked to describe their purchase criteria for pork and their source of information.

All discussions took up to $120 \mathrm{~min}$, were recorded and verbatim transcribed afterwards. A content analysis following a category system was used to structure the main results (based on [49]). It included the main categories of outdoor access and fresh air supply, farm design and flooring type, sources of engagement, space availability, surgical interventions and medication. Content analysis was performed with "MAXQDA Plus 12". Referring to rules of qualitative research methods, the chosen categories were discussed together within the project team in close coordination. In the case of this study, the results of the discussions were basal for the following quantitative online survey which is almost representative for the German population regarding several quotas.

\subsection{Online Survey}

Based on the outcomes of the focus groups, an online survey among German citizens was developed and conducted in 2017. The survey was administered by a private market research company. 
Requirements were a total of 2400 respondents (six times approximately 400 respondents for the different production types), meeting specified sociodemographic quotas. One question was "How concrete is your personal idea about today's majority of the following types of agricultural livestock?" Those respondents stating that their knowledge on pig fattening was concrete up to very concrete were assigned to the "fattening pig sample". "Fattening pig" was defined as follows: "This means the keeping of pigs for pork production. The period of fattening is considered, i.e., after separation from the mother sow until it reaches its slaughter weight".

The sample was widely representative for the German population with regard to gender, region and age but except for education, employment status and income (compare Table 1). Respondents with a professional background in agriculture or market research and people having participated in a survey on agriculture or nutrition in the last six months were excluded. Respondents answered questions concerning, among others, their dietary habits, their trust in media and different organizations as well as socio-demographics. Additionally, respondents assessed different types of livestock farming (Figure 1) and 45 items on a seven-point Likert scale which ranged from 1 "I do not agree at all" to 7 "I totally agree". These items were based on statements made by the participants in the focus groups. The items focused on outdoor access (Figure 2), the pigs' farm (Figure 3), sources of engagement (Figure 4), available space (Figure 5), surgical interventions (Figure 6) and medical treatment (Figure 7). Based on the experience from the focus groups, respondents were given information in case of surgical interventions via the text in brackets ("Usual surgical interventions in pig husbandry are tail docking, teeth grinding and castration of male piglets"). Analysis was carried out using IBM SPSS Statistics 26.

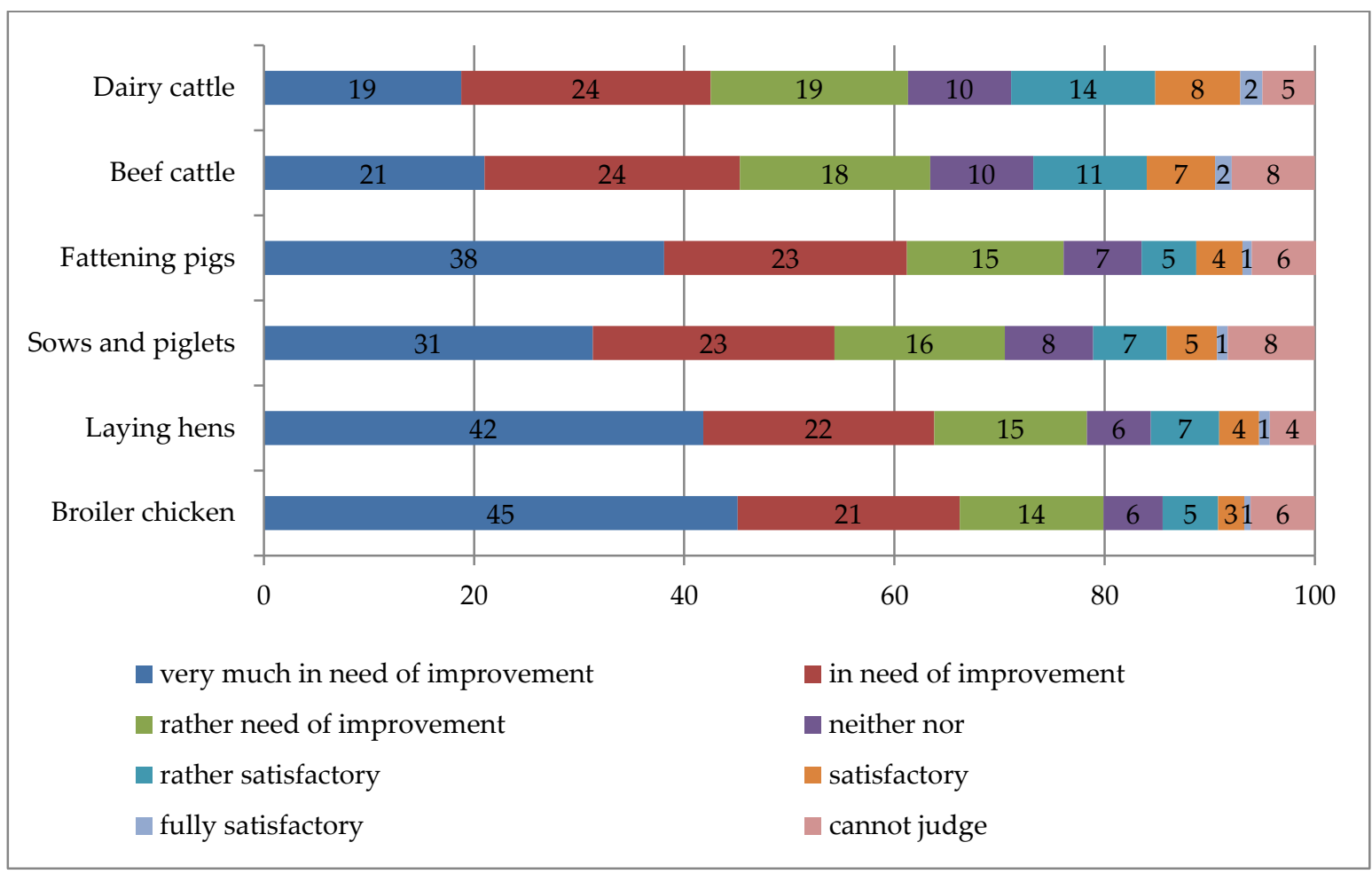

Figure 1. Respondents' assessment of different types of livestock farming. 
Table 1. Sample characteristics.

\begin{tabular}{|c|c|c|c|}
\hline & Absolute & Relative (\%) & Germany $(\%)$ \\
\hline Sample size & 399 & 100 & - \\
\hline \multicolumn{4}{|c|}{ Sex } \\
\hline Male & 172 & 56.9 & 49.3 \\
\hline Female & 227 & 43.1 & 50.7 \\
\hline \multicolumn{4}{|c|}{ Age } \\
\hline Mean age & 40.0 & & 44.3 \\
\hline 35 or younger & 151 & 37.8 & 36.83 \\
\hline 36 up to 55 & 166 & 41.6 & 28.33 \\
\hline 56 or older & 82 & 20.6 & 34.84 \\
\hline \multicolumn{4}{|c|}{ Income } \\
\hline $\begin{array}{l}\text { Median of households' net monthly } \\
\text { income (in Euro) }\end{array}$ & $2000-2599$ & 18.3 & $\begin{array}{c}3461 \\
\text { (Mean Income) }\end{array}$ \\
\hline \multicolumn{4}{|c|}{ Place of residence } \\
\hline North Germany & 63 & 15.8 & 16.1 \\
\hline West Germany & 131 & 32.8 & 35.2 \\
\hline East Germany & 83 & 20.8 & 19.5 \\
\hline South Germany & 122 & 30.6 & 29.0 \\
\hline \multicolumn{4}{|c|}{ Highest education level } \\
\hline $\begin{array}{l}\text { Without a school-leaving qualification } \\
\text { (yet) }\end{array}$ & 2 & 0.5 & 4.0 \\
\hline $\begin{array}{l}\text { German Volksschule or Hauptschule (8-9 } \\
\text { school years) }\end{array}$ & 34 & 8.5 & 29.6 \\
\hline $\begin{array}{l}\text { German "Realschule" or Polytechnic } \\
\text { secondary school (10 school years) }\end{array}$ & 76 & 19.0 & 29.9 \\
\hline $\begin{array}{l}\text { Qualification to study at college or } \\
\text { university }\end{array}$ & 69 & 17.6 & 32.5 \\
\hline Vocational training & 127 & 31.8 & 56.3 \\
\hline $\begin{array}{l}\text { University of applied science or } \\
\text { university degree }\end{array}$ & 91 & 22.8 & 16.8 \\
\hline \multicolumn{4}{|c|}{ Employment } \\
\hline Employed & 207 & 51.9 & 46.5 \\
\hline Unemployed, in qualification or retired & 192 & 48.1 & 53.5 \\
\hline \multicolumn{4}{|c|}{ Household } \\
\hline Mean number of persons & 2.28 & & 2.0 \\
\hline Household with children & 121 & 30.3 & 27.0 \\
\hline Farm visit in the past & 296 & 74.2 & - \\
\hline Ownership of pets & 224 & 56.1 & - \\
\hline Being vegetarian or vegan & 22 & 5.5 & 5.0 \\
\hline
\end{tabular}

Source: own calculation $[23,53]$.

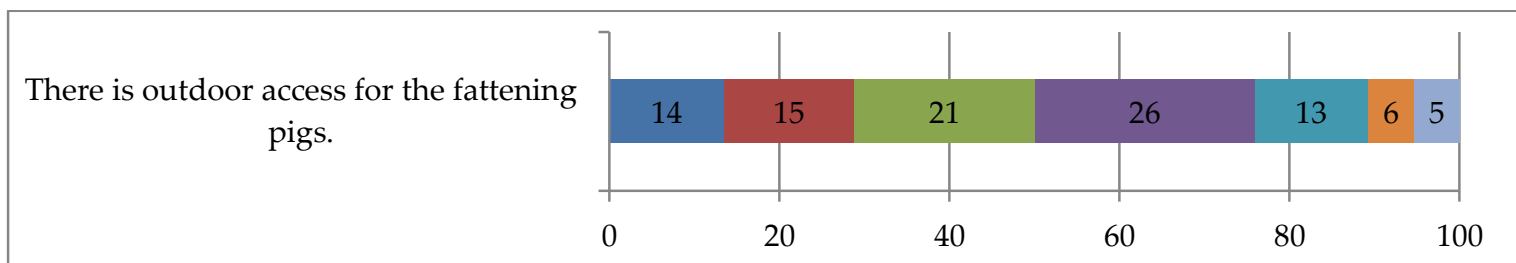

do not agree at all $\square$ do not agree $\square$ rather disagree $\square$ neither nor $\square$ rather agree $\square$ agree $\square$ agree at all

Figure 2. Frequency distribution of the statement "There is outdoor access for the fattening pigs". 
There is no litter in the barn (e.g. straw, sawdust, etc.).

The pigs have different areas (for sleeping, eating, walking) in their stable.

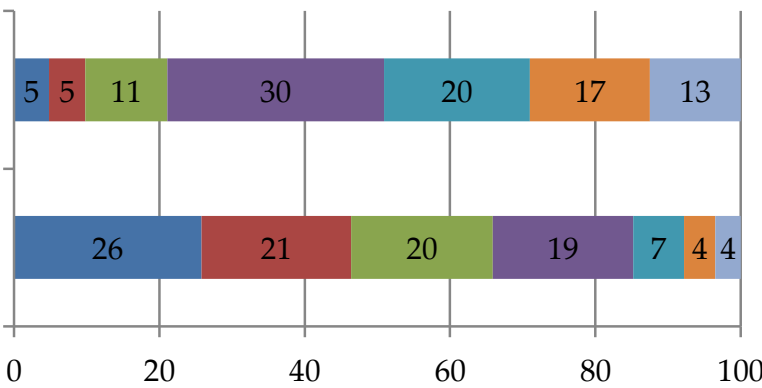

$\square$ do not agree at all $\square$ do not agree $\square$ rather disagree $\square$ neither nor $\square$ rather agree $\square$ agree $\square$ agree at all

Figure 3. Frequency distribution of the statements regarding the pig farm.

The pigs have various employment opportunities (e.g. toys) in the barn.

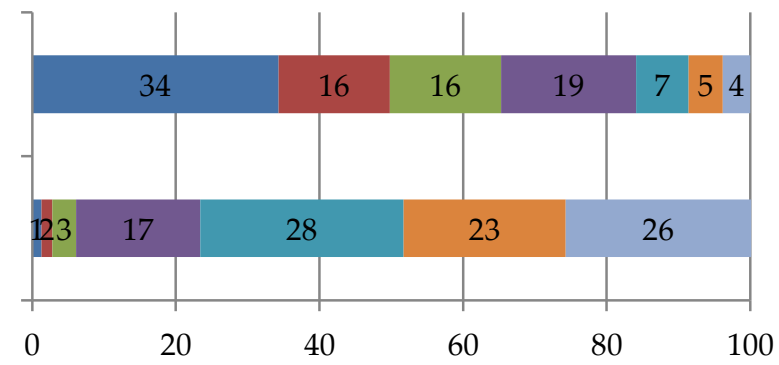

$\square$ do not agree at all $\square$ do not agree $\square$ rather disagree $\square$ neither nor $\square$ rather agree $\square$ agree $\square$ agree at all

Figure 4. Frequency distribution of the statements regarding engagement and intelligence.

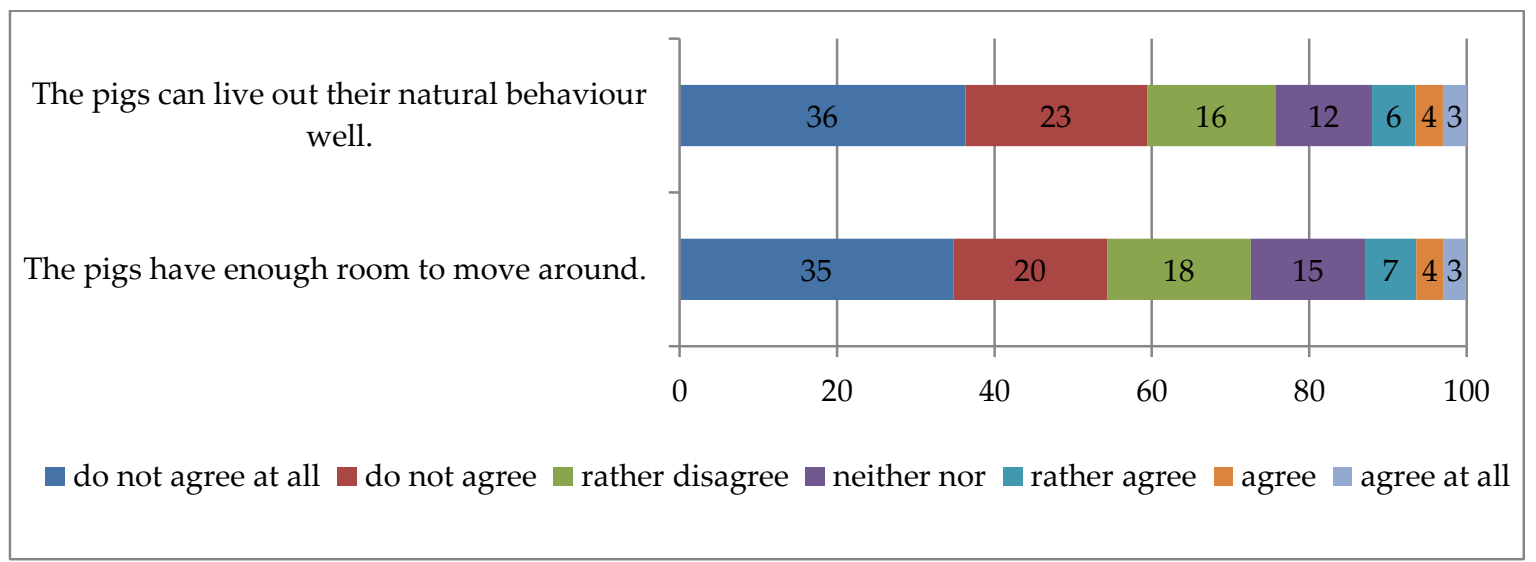

Figure 5. Frequency distribution of the statements regarding available space and natural behavior. 
Interventions on the pig, e.g. shortening of tails, castration or grinding of teeth are performed.

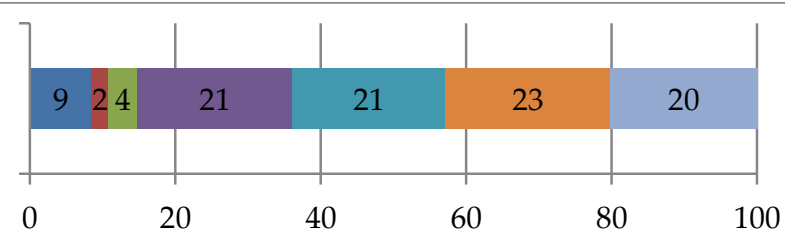

do not agree at all $\square$ do not agree $\square$ rather disagree $\square$ neither nor $\square$ rather agree $\square$ agree $\square$ agree at all

Figure 6. Frequency distribution of the statements regarding surgical interventions.

The use of medication (e.g. antibiotics) is necessary in this type of farming of pigs.

Drugs are also used to increase the performance of the pigs (more meat).

The pigs are only given medication when they are really sick.

The pigs get medicine as a precaution.

The use of medication is critical in this type of husbandry.

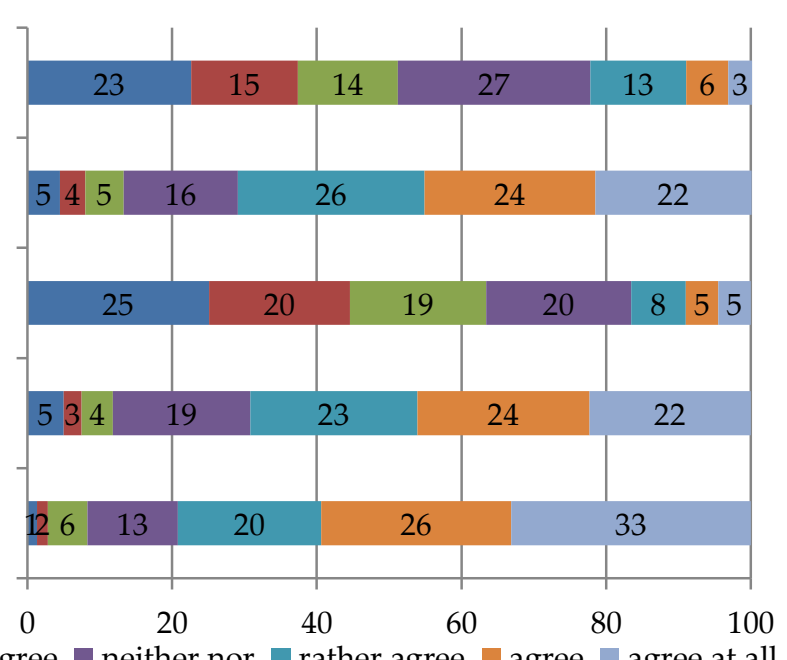

do not agree at all $\square$ do not agree $\square$ rather disagree $\square$ neither nor $\square$ rather agree $\square$ agree $\square$ agree at all

Figure 7. Frequency distribution of the statements regarding medical treatment.

\section{Results}

First, the main results of the focus group discussions are described. Second, the results of the online survey are presented.

\subsection{Focus Group Discussions}

In the following, the discussion contents by the participants are described in more detail for the different categories of outdoor access and fresh air supply, farm design and flooring type, sources of engagement, space availability, surgical interventions and medication.

\subsubsection{Outdoor Access and Fresh Air Supply}

The majority of the discussants mentioned that fattening pigs in recent husbandry conditions would mainly have no outdoor access and are kept only indoor in farms. However, it is conceded that on organic or smaller farms, the animals would regularly go outside. The lack of outdoor access was occasionally mentioned by the participants in connection with the term "factory farming" that was described negatively. It was also assumed that there is rarely fresh air supply in the farms, instead an "ammonia smell" was mentioned. Continuous supply of fresh air would be replaced by exhaust air systems, ventilation or filter systems. It was sometimes stressed by the discussants that pig husbandry largely takes place behind closed doors or in closed systems.

\subsubsection{Farm Design and Flooring Type}

The participants only had a sporadic picture of different farm areas and were not able to give a description of more details. They talked about corridors that must be available for the staff working 
on the farms. In addition, walls, fences or boxes, bays and plots were mentioned. They described the equipment of the pig farm only rarely and mentioned that it differs depending on the branch of production. The statements about flooring types were mainly including "gaps" and "grids". Other floor coverings such as concrete or rubber were mentioned less frequently by the discussants. Furthermore, the floor was sometimes described as "dirty" or "full of excrements". Straw was almost never mentioned. It was often justified that slatted or grid floors are used because they are permeable and, therefore, must not be mucked out. Discussants sometimes explained the negative consequences of slatted and grid floors as being unpleasant for the animals or as not being a natural surface for pigs. A risk of injury arising from this was frequently mentioned by the participants.

\subsubsection{Sources of Engagement}

Some statements referred to balls or chains as possibilities to engage the pigs. However, the discussants mostly mentioned that the animals could only eat and drink which was considered to be the only engagement opportunity. In this context, (long) troughs and water troughs were described which would be available as equipment on the farms. The specific question about engagement possibilities was often answered by the fact that the animals could only engage in minimal physical activity, e.g., by "standing", "breathing", "grunting" or "sleeping". Following the participants, there would be no distraction or playing opportunities for the animals or nothing they could do in the farms in most cases. Some discussants emphasized that pigs are intelligent animals that actually want to be occupied as otherwise they would become ill.

\subsubsection{Space Availability}

It was mentioned that it is "cramped" in the farms, the animals are "wedged in" and "squeezed in" or that there would be "no space" available for the animals. On the other hand, it was very rarely mentioned by some discussants that there would be more space for the animals on organic farms. In many statements of the participants, the insufficient freedom to move for the animals was explicitly mentioned. But they also described that it is not desirable at all that the pigs move a lot because they would gain weight slower than they would do without moving.

\subsubsection{Surgical Interventions}

Regarding this category, participants made the statements mainly in response to a short explanation about castration as a usual method. In some cases, apart from vaccinations or injections which were often considered to be mutilations on the animals, there were no others in participants' perceptions. If castrations were discussed, the main question was whether they were economically profitable. The procedure of a castration was occasionally described in detail by the discussants and it was pointed out that the animals were not stunned. Again, the economic aspect was taken up and it was emphasized that the renunciation of stunning had economic reasons and should save time. In contrast, some discussants reported that stunning was carried out during castration. They explained that it is an operation like for pets which would be harmless.

\subsubsection{Medication}

When discussions came to medication, antibiotics were most frequently discussed. Sometimes, participants explained that the use of antibiotics is prophylactic to prevent diseases or injuries resulting from poor husbandry conditions. The preventive administration of antibiotics was rated very critically by some of the discussants. Furthermore, discussants mentioned wounds caused by tail-biting due to lack of space per animal and the boredom of the animals that makes analgesics necessary. Besides, they talked about possible injuries of the claws caused by slatted floors. In addition, antidepressants were mentioned in individual cases as the pigs suffered from depression due to the housing conditions and the lack of opportunities for exercise or employment. In total, participants pointed out that physical or emotional stress for the animals as well as the various drugs could affect the final product 
meat. Especially the preventive administration of antibiotics was rated very critically by some of the participants in the discussion. Following the discussants, the safety of the consumers when eating meat was partly doubted because of antibiotic resistances.

\subsection{Online Survey}

More male than female respondents answered (56.9\% compared to $43.1 \%$ ) (see Table 1). The respondents mean age was 40.00 years (ranging from 18 to 76 years); persons younger than 18 were not sampled. The mean household size was 2.28 , and children lived in $30.3 \%$ of the households. The most striking difference between our sample and the general German population is the education status. It was, on average, higher for the analyzed sample where $22.8 \%$ of respondents had a university degree compared to $16.8 \%$ in Germany. The mean household size in our sample was larger (2.54) compared to the general German population (2.0), and the median monthly net income was in the interval of EUR 2000-2500 and smaller compared to the German average (EUR 3461). A large number of respondents had visited a farm in the past $(74.2 \%)$ and $5.5 \%$ had a vegetarian/vegan diet. Despite certain deviations, it can be assumed that the sample constitutes a fairly good representation of the German population.

One of the first questions was "How do you assess the current prevalent forms of husbandry of the following farm animal species?" Results are presented in Figure 1 and show that the management of fattening pigs was seen by $75 \%$ of the respondents as in need of improvement, while $70 \%$ saw room for improvement in sow management and piglet production.

The results also show that more respondents considered the keeping of broiler chickens and laying hens to be in need of improvement compared to fattening pigs. Dairy cattle farming was rated most positively. A total of $24 \%$ of the respondents rated it as satisfactory, and $62 \%$ saw room for improvement there. The beef cattle farming was rated similarly. A total of $63 \%$ of the respondents rated it as in need of improvement.

In the following, the quantification of the items derived from the focus groups will be presented. Each topic presented in Section 3.1 was questioned using up to five statements ranging from 1 (do not agree at all) to 7 (agree at all).

\subsubsection{Outdoor Access and Fresh Air Supply}

From Figure 2 it is obvious that about 50\% did not believe that pigs have outdoor access and $26 \%$ cannot decide between agreement and disagreement. Less than $25 \%$ perceived pigs to have outdoor access.

The mean for this statement was 3.48, and the standard deviation (SD) was 1.613. Results point out the skepticism towards outdoor access as the median was 3 (rather disagree).

\subsubsection{Farm Design and Flooring Type}

Within Figure 3, the frequencies regarding the farms are presented. About $50 \%$ agreed that there is no litter in the barns, $30 \%$ were unsure and about $20 \%$ did not believe in this statement. Regarding different areas in the farm, the picture was even clearer: about $65 \%$ disagreed with the statement meaning that they did not believe that pigs have different areas, $20 \%$ could not decide and about $15 \%$ thought that there are different areas in the pig farms. Therefore, respondents were more convinced that pigs do not have different areas than those having no litter in the barns.

Differences between the answers of the two statements are even clearer if the means and medians are compared. While the mean of the first statement (litter) was $4.55(\mathrm{SD}=1.56)$, it was $2.88(\mathrm{SD}=1.63)$ for the second one (different areas). Comparing the median, it was 4 in case of litter (neither nor) and 3 in case of different areas (rather disagree). 


\subsubsection{Sources of Engagement}

Results about sources of engagement or pigs' intelligence in respondents' perception are similarly clear or even clearer than those regarding the farm (see Figure 4). About $65 \%$ of the respondents did not think that pigs have any sources of engagement and about 15\% did. In case of pigs' intelligence, the result is extremely clear: more than $75 \%$ agreed with the statement that pigs are intelligent animals, $17 \%$ chose "neither nor" as an answer and only less than $7 \%$ did not agree.

The median of the statement concerning pigs' engagement was 3 (rather disagree), and the was mean only $2.78(\mathrm{SD}=1.73)$. Regarding pigs' intelligence, the median was 5 (rather agree), and the mean was even $5.41(\mathrm{SD}=1.32)$.

\subsubsection{Space Availability}

Regarding the available space and the relating possibility to move out natural behavior, Figure 5 paints a clear picture: in both cases more than $70 \%$ denied the statements (the statement concerning the natural behavior was more denied) and between $12 \%$ and $15 \%$ were undecisive meaning that only less than $15 \%$ agreed with the presented statements.

The median for both statements was 2 (do not agree), and the mean values were 2.6 for sufficient space and 2.5 for natural behavior. Standard deviation was 1.61 both times.

\subsubsection{Surgical Interventions}

This statement seemed to be quite difficult for the respondents, as more than $20 \%$ were not able to agree or disagree. Almost $65 \%$ agreed with the statement, and less than $15 \%$ thought that interventions on pigs are not carried out (compare Figure 6).

The descriptive analysis showed a median of 5 and a mean of almost $4.93(\mathrm{SD}=1.73)$.

\subsubsection{Medication}

Several statements were raised to quantify the results from focus group discussions about the perceived medical treatment of fattening pigs (compare Figure 7). Regarding the necessity of a medical treatment in modern pig husbandry, more than a quarter was not able to adopt a clear position. More than $50 \%$ disagreed and less than $25 \%$ agreed. The other statements were answered even more clearly. More than $70 \%$ agreed that drugs are given to increase pigs' performance ( $16 \%$ undecided) and just a bit more than $15 \%$ thought that pigs are just medically treated in case of illnesses ( $20 \%$ undecisive).

That medication is also given prophylactically was believed by almost $70 \%$ (19\% unsure), and almost $80 \%$ perceived the medical treatment to be critical (13\% neither nor). Thus, only less than $10 \%$ of the respondents (rather) disagreed with the statement that the medication is critical.

Statistical results underline the found results from frequency distributions. The statement regarding the necessity of medication had a mean of $3.24(\mathrm{SD}=1.69)$, regarding medication in case of illness: of $2.97(\mathrm{SD}=1.68)$ and regarding the performance enhancing use of drugs: of $5.12(\mathrm{SD}=1.58)$. The item about the precautionary principle received a mean of $5.13(\mathrm{SD}=1.58)$, and the item that states that the medication is critical had a mean of $5.59(\mathrm{SD}=1.39$ ). Medians were 3 for statements regarding the necessity and situation when drugs are given, 5 for the perceived performance enhancing use of drugs and the prophylactically use and 6 for the statements that the use of medication is critical.

\subsubsection{Analysis of Possible Dependencies}

Each of the statements presented in Sections 3.2.1-3.2.6 was analyzed for dependencies with each variable presented in Table 1 using cross tabulations. In the following Table 2, only significant results are presented. If proficiency is not described, this means that there has been no deviation from the expected value for it. 
Table 2. Analysis for dependencies.

\begin{tabular}{|c|c|}
\hline Statement/Variable & Strength \\
\hline \multicolumn{2}{|c|}{ There is outdoor access for the fattening pigs. } \\
\hline Age ** & 0.179 \\
\hline 35 or younger & More often disagreement, less often agreement \\
\hline 56 or older & More often agreement, less often disagreement \\
\hline Farm visit $* * *$ & 0.207 \\
\hline Yes, more than once & More often disagreement, less often neither nor \\
\hline Yes, one time & Less often disagreement or agreement, more often neither nor \\
\hline No, never & More often neither nor, less often agreement \\
\hline Being vegetarian or vegan ** & 0.138 \\
\hline Yes & More often disagreement, less often agreement \\
\hline \multicolumn{2}{|c|}{ There is no litter in the barn (e.g., straw, sawdust, etc.). } \\
\hline Farm visit $* * *$ & 0.234 \\
\hline Yes, more than once & More often agreement, less often neither nor \\
\hline Yes, one time & More often disagreement or neither nor, less often agreement \\
\hline No, never & Less often disagreement or agreement, more often neither nor \\
\hline \multicolumn{2}{|c|}{ The fattening pigs have different areas (for sleeping, eating, walking) in their stable. } \\
\hline Farm visit * & 0.160 \\
\hline Yes, more than once & More often disagreement or agreement, less often neither nor \\
\hline Yes, one time & Less often disagreement, more often neither nor \\
\hline No, never & More often disagreement or neither nor, less often agreement \\
\hline Income ${ }^{* *}$ & 0.167 \\
\hline Less than EUR 1300 & More often disagreement, less often agreement or neither nor \\
\hline EUR 1300-2599 & Less often disagreement, more often agreement \\
\hline More than EUR 2599 & Less often disagreement, more often neither nor \\
\hline Boing yogetarian or yeoan * & 0.115 \\
\hline Being vegetarian or vegan & More often disagreement \\
\hline & Less often agreement or neither nor \\
\hline \multicolumn{2}{|c|}{ The fattening pigs have various engagement opportunities (e.g., toys) in the barn. } \\
\hline $\operatorname{Sex} * * *$ & 0.160 \\
\hline Being female & More often disagreement, less often agreement \\
\hline Having pets * & 0.113 \\
\hline Yes & More often disagreement, less often neither nor \\
\hline Being vegetarian or vegan * & 0.118 \\
\hline Yes & More often disagreement, less often neither nor \\
\hline \multicolumn{2}{|c|}{ I believe that fattening pigs are intelligent animals. } \\
\hline Being vegetarian or vegan * & 0.108 \\
\hline Yes & More often agreement, less often disagreement or neither nor \\
\hline \multicolumn{2}{|c|}{ The fattening pigs have enough room to move around. } \\
\hline Sex * & 0.117 \\
\hline Being female & More often disagreement, less often agreement or neither nor \\
\hline Farm visit * & 0.173 \\
\hline Yes, more than once & More often disagreement, less often neither nor \\
\hline Yes, one time & Less often disagreement, more often agreement or neither nor \\
\hline No, never & More often disagreement or neither nor, less often agreement \\
\hline
\end{tabular}


Table 2. Cont.

\begin{tabular}{|c|c|}
\hline \multicolumn{2}{|c|}{ The fattening pigs can live out their natural behaviour well. } \\
\hline Sex * & 0.117 \\
\hline Being female & More often disagreement, less often agreement \\
\hline \multicolumn{2}{|c|}{ The use of medication (e.g., antibiotics) is necessary in this type of farming of fattening pigs. } \\
\hline $\operatorname{Sex}^{* * *}$ & 0.276 \\
\hline Being female & More often disagreement or neither nor, less often agreement \\
\hline Age * & 0.141 \\
\hline 35 or younger & Less often disagreement, more often agreement or neither nor \\
\hline 36 up to 55 & More often disagreement, less often agreement or neither nor \\
\hline 56 or older & More often disagreement, less often agreement or neither nor \\
\hline Being vegetarian or vegan * & 0.121 \\
\hline Yes & More often disagreement, less often agreement or neither nor \\
\hline \multicolumn{2}{|c|}{ The fattening pigs are only given medication when they are really sick. } \\
\hline Farm visit $* * *$ & 0.249 \\
\hline Yes, more than once & More often disagreement or agreement, less often neither nor \\
\hline Yes, one time & Less often disagreement, more often agreement \\
\hline No, never & Less often disagreement or agreement, more often neither nor \\
\hline \multicolumn{2}{|c|}{ The use of medication is critical in this type of husbandry. } \\
\hline Age * & 0.147 \\
\hline 35 or younger & More often disagreement, less often agreement or neither nor \\
\hline 36 up to 55 & Less often disagreement, more often agreement or neither nor \\
\hline 56 or older & Less often disagreement, more often agreement \\
\hline
\end{tabular}

${ }^{*}$ Significance Level $=0.1 ; * *$ Significance Level $=0.05 ; * * *$ Significance Level $=0.01$. Strength of the correlation: $<0.200=$ very weak; $0.200-0.399=$ weak. Source: own calculations.

Three out of thirteen statements showed no dependencies with even one of the sociodemographic variables. The variables "farm visit" and "being vegetarian or vegan" were the ones with the most dependencies (five). No dependencies were found for the sociodemographic variables of place of residence, education, employment and household with children. However, even if dependencies were found, only very weak up to weak effects were detected. In case of cross tabulations, the value for the strength can be interpreted in the same way as the correlation coefficient. However, the value just shows the strengths of the correlation but not its direction.

\section{Discussion}

The objective of this study was to analyze citizens' perceptions towards the husbandry of fattening pigs using a mixed-methods approach. All in all, the results illustrate the advantages of a mixed-method approach. With the help of the focus groups, non-representative individual opinions were specifically recorded in order to capture the range of ideas and also to obtain possible explanations for them. The quotations from these discussions are impressive in their authenticity, even if it remains unclear to what extent these opinions are transferable to the population. By contrast, the data from the quasi-representative online survey provide reliable results that can no longer be described as random.

The results of the focus groups were broadly confirmed by the survey. However, it must be noted that the results of the focus groups appear more authentic and sometimes more extreme due to the individually spoken word of a few participants. Nevertheless, focus groups indicate no general or representative results and their interpretation requires care. Combining them with the following online survey allows a comprehensive perspective of actual citizens' perceptions towards fattening pig production.

The number of respondents with a detailed knowledge was high and can be explained by the fact that we asked whether their personal idea about fattening pigs was concrete or not. Only those who stated that their knowledge was concrete were assigned to the fattening pigs sample. Nevertheless, 
it is noticeable that about one third of the respondents was not able to give a clear answer to some statements (e.g., if outdoor access is provided for fattening pigs, see Figure 2). Several different interpretations of this result are imaginable. Firstly, this result may indicate citizens' perceptions about the different types of pig husbandry: e.g., media reports mainly send pictures from indoor keeping with high stocking densities, but respondents are aware of the fact that there is a number of farms providing outdoor access for their pigs. Another interpretation of this result could be seen in the disliking to consider animal husbandry intensively, which was found for people with meat-based diets [42]. Furthermore, this result may reflect the respondents' knowledge that there is a gap between their perception and reality. This was found by [29]. Because of the differences between citizens' perceptions and reality, they concluded that visits to farms should be offered for critics and media representatives to demonstrate transparency. A Canadian study about visits to dairy farms indicates that knowledge may overcome some concerns about husbandry practices, but other ones will continue afterwards [54]. This explanation could also apply in the case of pigs.

Previous farm visits had a strong influence on the response to numerous statements. Interestingly, it was decisive whether there had been one or more farm visits in the past. Respondents who had visited a farm more than once showed a very realistic idea of the husbandry that is common today. In contrast, people who had only visited a farm once showed a less realistic picture. The reasons for this can only be presumed: It is possible that those respondents who visited a farm only once did this during childhood and/or visited an organic farm. Those respondents who visited a farm more than once might be more engaged in the topic. This interest could lead to an increased search for information resulting in more farm visits and visits to different farms. Results can be compared to those of [11] who found that especially those respondents with a better knowledge of agriculture rejected pig farming more often.

In relation to the research questions posed at the beginning, the following can be said in summary.

RQ1 (perception): Most of our results confirm previous studies: Citizens' perception of fattening pigs' husbandry is mostly very critical. Many aspects, such as the lack of space, are well known. Sometimes, detailed knowledge is missing (e.g., in case of surgical interventions).

Negative imaginations from crowded farms with high stocking densities were recognized in the discussions, and it seemed that the description was of stables with the legally permissible amount of space and not of unlawful ones. Reasons might be critical media reports, dealing with negative examples of fattening pig husbandry and pictures of farms with high stocking densities, as media reports contribute to an increasing awareness about the reality of fattening pigs' housing conditions [55]. For instance, details of watched films were described by the participants very precisely. In some other cases, results show that some participants (focus groups as well as survey) did not have a very clear perception of farm design or equipment, as assumptions do not correspond or correspond only partially to agricultural practice (e.g., offering sources of engagement for pigs is mandatory in Germany).

Limited space per animal and high stocking densities are already known as a critical point of recent pig farming in several countries for longer times [10,56,57]. As previous studies from Germany show, especially space per animal is an important factor of pig husbandry [9-11]. When purchasing higher animal welfare products, it is seen as the most important factor in the survey of [24].

Flooring type was a strong discussed topic in the focus groups, especially as a possible risk for injuries caused by slatted floors which are usually in discussants' perception. The affection to pigs' health was also seen by [11]. In contrast, referring to the study of [24], flooring type and possibilities to root are less important criteria of pig husbandry compared with space availability and outdoor access [24].

Results of the survey concerning sources of engagement and pigs' intelligence fit extremely well to the results of the focus groups. Discussants described pigs as intelligent animals which want to be engaged. Although sources of engagement are obligatory in Germany, about 2/3 of the survey respondents did not agree that pigs are offered those materials. In contrast, following [24], sources of engagement and for playing are the less important criteria of the five presented in a survey about 
pig welfare. A reason might be a lack of knowledge by citizens about the possibilities to engage pigs. According to the study [31], wooden toys for pigs were mainly not even recognized as such by respondents while looking at pictures from pig farms. Following the results of [11], a lack of engagement may affect pigs' welfare [11]. Furthermore, the discussion on pigs' intelligence and the need for "toys" fit well to the frame "individuality" derived in [57].

In case of the focus groups as well as the survey, at least some information about surgical interventions was given. Additionally, our qualitative study shows that surgical interventions like tail docking were not very well known by the respondents, although they are usual practice in fattening pig farming. This is in line with older surveys which show less importance or even interest of surgical interventions e.g., [11,17], and that although there was an on-going public discussion about alternatives of surgical castration of male piglets without pain relief and their economic impact within the last years [58].

The perceived prophylactic medication was discussed extremely critically. Only $15 \%$ of our survey respondents believed that drugs are only given in case of illness. Many discussants talked about the preventive use of medication, especially antibiotics. The findings fit extremely well to those of [11], which also showed that respondents fear negative effects on their own health with regard to drug administration.

Only weak to very weak dependencies were found for the analyzed sociodemographic variables. The dependencies that were found between sociodemographic variables and the responses to our statements are in line with other studies. As we did not carry out a cluster analysis, results can be compared in a more indirect way, meaning that critical assessments were interpreted in opposition to our presented statements. Keeping this in mind, the following comparisons can be made: Women were also found to be more critical by $[10,11,52]$. It seems obvious that respondents with a vegetarian or vegan diet are more critical or averse to current fattening pig farming. However, we have not found evidence for this in quantitative studies so far and conclude that this variable has not been questioned very often yet.

RQ2 (main points of criticism): Although respondents criticized almost every aspect of pigs' husbandry, space availability and (perceived) medication were the most criticized aspects in the focus groups as well as in the survey. Again, this is in line with [11], which found the aspects of more space, outdoor access and no prophylactic use of antibiotics to be the most important aspects.

RQ3 (conclusions against the background of the current public debate): Due to the social criticism towards fattening pig production, the sector is at risk of losing its license to operate. An improvement can only be achieved through various measures and rapid success should not be expected.

In a first step, information campaigns might help at least in part with respect to some specific aspects because only if the public notices enhancements, will public perception have a chance to improve. In case of dairy cattle, a study dealing with the provision of information about husbandry aspects has shown that brief explanatory information could influence respondents' views in part but does not result in clear acceptance [59]. There have already been several enhancements regarding pigs' medication (e.g., antibiotic monitoring), and the use of antibiotics in fattening pig farming has fallen by $46 \%$ in recent years [60]. Nevertheless, it is necessary to check farmers' compliance with the rules regularly. Regular controls and the communication of the results might help improving societal perception, as the lack of sufficient controls was often perceived and discussed very critically in our study but also in the one of other researchers [10,11]. Additionally, the fact that material for engagement is mandatory could be explained.

The mentioned enhancements are costly; good campaigns are too expensive for individual farmers to finance. Therefore, we recommend that farmers' associations commission such a campaign and make it available to their members. Nonetheless, information is no panacea. According to [10], the better-informed respondents belonged to the group of opponents. It will be important that the enhancements are not used as an argument for not doing much more in the future as there is still a great deal of work to do. 
Our results do not show any explicit ways of improving social acceptance of farm animal husbandry. Nevertheless, the authors would like to share with the readers some general ideas for improving pig production: For improving societal perception and increasing public acceptance of fattening pig production in Germany, it would be primarily necessary to enhance the main points of criticism. In the short term, space availability could be increased by decreasing the number of animals per unit and sources of engagement could be bought. In the long-term, new fattening pig farms with sufficient space and different functional areas would be optimal for an increasing societal perception. However, even the short-term solution is at farmers' own risk, as additional costs due to employment materials or the reduced income due to a reduction in the stocking density lowers the profit. During times of low pork prices in Germany, "someone" has to compensate the farmers. Although the majority of questioned consumers state in surveys that they are willing to pay more for meat if pigs lived under good conditions before slaughtering, only a manageable proportion of them implement this already in reality. This phenomenon, that the attitudes of a person are not or only partially reflected in his or her behavior, is known in the literature as the consumer-citizens-gap [61]. In their role as citizens, many meat eaters are concerned about animal welfare and want the animals to have a good life before they die. In their role as consumers, they try to avoid thinking about the live animal [42]. Different strategies to cope with this gap are described in the literature [62]: some consumers start reframing themselves and argue that the fact that the animals suffer has to be accepted; others argue that this problem cannot be solved by the consumers and that a political solution must be found. The third way is to actively search out products produced under higher animal welfare standards. This third group is discussed comprehensively by [63]. The authors conclude that this group could be "agents of sustainable change" and they warn also against too much black-and-white-painting. Respondents in our focus groups but also the ones of [10] discussed their own responsibility very self-critically. However, as long as very cheap pork is offered in German supermarkets, it should not be expected that this will change a lot in future. This skepticism can also be justified on the basis of earlier studies [24,37-41].

Currently, an "animal welfare submission" is discussed in Germany to help to solve this problem as the earned money should be used to support farmers to improve husbandry conditions. This idea was already supported by various authors e.g., $[28,64,65]$ in the last years. Additionally, also because of the scandal at the German slaughterhouse Tönnies during the Covid-19-crisis [66], federal agriculture minister Julia Klöckner is supporting this idea [67].

Author Contributions: I.C.-S. was responsible for the conceptualization, investigation, methodology, analysis, validation, writing, editing and reviewing of the study. A.-K.R. was responsible for the investigation, methodology, validation, analysis, writing and editing of the study. All authors have read and agreed to the published version of the manuscript.

Funding: The project "SocialLab" was funded by the Federal Ministry of Food and Agriculture (BMEL) by decision of the German Bundestag. Within the innovation funding, the project is managed by the Federal Office for Food and Agriculture (BLE).

Conflicts of Interest: The authors declare no conflict of interest.

\section{References}

1. Tonsor, G.T.; Olynk, N.; Wolf, C. Consumer preferences for animal welfare attribute: The case of gestation crates. J. Agric. Appl. Econ. 2009, 41, 713-730. [CrossRef]

2. Vanhonacker, F.; Verbeke, W.; van Poucke, E.; Pieniak, Z.; Nijs, G.; Tuyttens, F. The concept of farm animal welfare: Citizen perceptions and stakeholder opinion in Flanders, Belgium. J. Agric. Environ. Ethics 2012, 25, 79-101. [CrossRef]

3. Ohl, F.; van der Staay, F.J. Animal welfare: At the interface between science and society. Vet. J. 2012, 192, 13-19. [CrossRef] [PubMed] 
4. Bergstra, T.J.; Hogeveen, H.; Stassen, E.N. Attitudes of different stakeholders toward pig husbandry: A study to determine conflicting and matching attitudes toward animals, humans and the environment. Agric. Hum. Values 2017, 34, 393-405. [CrossRef]

5. Laine, M.; Vinnari, E. The transformative potential of counter accounts: A case study of animal rights activism. Account. Audit. Account. J. 2017, 30, 1481-1510. [CrossRef]

6. Brümmer, N.; Salthammer, K.; Rovers, A.; Christoph-Schulz, I.; Wolfram, J. Das Abbild der Geflügelhaltung-Oder was im Gedächtnis bleibt. DGS Magazin für Geflügelwirtschaft 2018, 35, 42-45.

7. European Commission. Attitudes of Europeans towards Animal Welfare. Special Eurobarometer 442. Available online: http://ec.europa.eu/COMMFrontOffice/PublicOpinion/index.cfm/ResultDoc/download/ DocumentKy/71348 (accessed on 30 June 2020).

8. BMEL. Deutschland, Wie Es Isst. Der BMEL-Ernährungsreport. 2017. Available online: https://www.bmel.de/SharedDocs/Downloads/DE/Broschueren/Ernaehrungsreport2017.pdf;jsessionid= 67186736F196A91E350537CB51D5BE80.internet2832?_blob=publicationFile\&v=3 (accessed on 30 June 2020).

9. Wildraut, C.; Plesch, G.; Härlen, I.; Simons, J.; Hartmann, M.; Ziron, M.; Mergenthaler, M. Multimethodische Bewertung von Schweinehaltungsverfahren durch Verbraucher anhand von Videos aus realen Schweineställen. Forschungsberichte des Fachbereichs Agrarwirtschaft Soest. Available online: https://www4.fh-swf.de/media/ downloads/fbaw_1/forschung_1/forschungsberichte_1/Nr.36_2015_Schweinehaltung_und_Verbraucher.pdf (accessed on 20 July 2020).

10. Weible, D.; Christoph-Schulz, I.; Salamon, P.; Zander, K. Citizens' perception of modern pig production in Germany: A mixed-method research approach. Br. Food J. 2016, 118, 2014-2032. [CrossRef]

11. Zander, K.; Isermeyer, F.; Bürgelt, D.; Christoph-Schulz, I.; Salamon, P.; Weible, D. Erwartungen der Gesellschaft an die Landwirtschaft; Stiftung Westfälische Landwirtschaft: Münster, Germany, 2013.

12. Spooner, J.M.; Schuppli, C.A.; Fraser, D. Attitudes of Canadian citizens toward farm animal welfare: A qualitative study. Livest. Sci. 2014, 163, 150-158. [CrossRef]

13. Thompson, P.B.; Appleby, M.; Busch, L.; Kalof, L.; Miele, M.; Norwood, B.F.; Pajor, E. Values and public acceptability dimensions of sustainable egg production. Poult. Sci. 2011, 90, 2097-2109. [CrossRef]

14. Spiller, A.; Kayser, M.; Böhm, J. Unternehmerische Landwirtschaft zwischen Marktanforderungen und gesellschaftlichen Erwartungen in Deutschland ... aus Sicht der Forschung. Schr. Ges. Wirtsch. Sozial. Landbau. eV 2012, 47, 11-22.

15. Veldkamp, A.; Altvorst, A.C.; Eweg, R.; Jacobsen, E.; Kleef, A.; Latesteijn, H.; Mager, S.; Mommaas, H.; Smeets, P.J.A.M.; Spaans, L.; et al. Triggering transitions towards sustainable development of the Dutch agricultural sector: TransForum's approach. Agron. Sustain. Dev. 2009, 29, 87-96. [CrossRef]

16. te Velde, H.; Aarts, N.; van Woerkum, C. Dealing with ambivalence: Farmers' and consumers' perception of animal welfare in livestock breeding. J. Agric. Environ. Ethics 2002, 15, 203-219. [CrossRef]

17. Meuwissen, M.P.M.; van der Lans, I.A.; Huirne, R.B.M. A synthesis of consumer behavior and chain design. Available online: http://www.greenpiggery.org/documenten/Chain2004PaperMeuwissen.pdf (accessed on 20 June 2020).

18. Grunert, K.G.; Sonntag, W.I.; Glanz-Chanos, V.; Forum, S. Consumer interest in environmental impact, safety, health and animal welfare aspects of modern pig production: Results of a cross-national choice experiment. Meat Sci. 2018, 137, 123-129. [CrossRef]

19. Agrarmarkt Informations-Gesellschaft mbH (AMI). Available online: https://www.ami-informiert.de/ fileadmin/shop/leseproben/AMI-MarktBilanz_Vieh_Fleisch_2020_IHVZ_.pdf (accessed on 20 June 2020).

20. BVE. Jahresbericht. 2018-2019. Available online: https://www.bve-online.de/presse/infothek/publikationenjahresbericht/bve-jahresbericht-ernaehrungsindustrie-2019 (accessed on 20 July 2020).

21. BLE. Versorgung mit Fleisch in Deutschland im Kalenderjahr 2019 (Vorläufig). 2017-2018. Available online: https://www.ble.de/DE/BZL/Daten-Berichte/Fleisch/fleisch_node.html (accessed on 20 July 2020).

22. MRI. Nationale Verzehrsstudie II. Ergebnisbericht. Available online: https://www.bmel.de/DE/Ernaehrung/ GesundeErnaehrung/_Texte/NationaleVerzehrsstudie_Zusammenfassung.html (accessed on 20 July 2020).

23. BMEL. Deutschland Wie Es Isst-Der BMEL Ernährungsreport. 2020. Available online: https://www.bmel.de/DE/themen/ernaehrung/ernaehrungsreport2020.html (accessed on 20 July 2020). 
24. Enneking, U.; Kleine-Kalmer, R.; Dauermann, A.; Voigt, R. Kaufbereitschaft bei verpackten Schweinefleischprodukten im Lebensmitteleinzelhandel-Realexperiment und Kassenzonen-Befragung. Agrarund Lebensmittelmarketing. Hochschule Osnabrück. Available online: https:/www.hs-osnabrueck.de/ fileadmin/HSOS/Homepages/Personalhomepages/Personalhomepages-AuL/Enneking/Tierwohlstudie-HSOsnabrueck_Teil-Realdaten_17-Jan-2019.pdf (accessed on 30 June 2020).

25. Rovers, A.K.; Brümmer, N.; Saggau, D.; Christoph-Schulz, I.B. Wahrnehmung der Schweinehaltung: Ergebnisse aus Gruppendiskussionen mit Bürgern in Deutschland. Berichte Über Landwirtschaft 2019, 97, 1-15.

26. Sonntag, W.I.; Kiehas, M.T.; Spiller, A.; Kaiser, A.; Ludolph, L.-M.; Grunert, K.G.; von Mayer-Höfer, M. Consumer evaluation of intra-sustainable trade-offs in pig production-A mixed-method approach to analyze different consumer segments. Livest. Sci. 2018, 224, 102-113. [CrossRef]

27. Sonntag, W.I.; Kaiser, A.; von Meyer-Höfer, M.; Spiller, A. Wie können Ansprüche der Gesellschaft in mögliche Veränderungsprozesse eingebunden werden? Konfrontation von Verbrauchern mit Zielkonflikten aus der Schweinehaltung. Berichte Über Landwirtschaft 2017, 95, 1-27.

28. BMEL. Wege Zu Einer Gesellschaftlich Akzeptierten Nutztierhaltung. Available online: https://buel.bmel.de/ index.php/buel/article/view/82 (accessed on 30 June 2020).

29. Ermann, M.; Graskemper, V.; Spiller, A. Die Wirkung von geführten Stallbesichtigungen auf Bürger-Eine Fallstudie auf nordwestdeutschen Schweinemastbetrieben. Schr. Ges. Wirtsch. Sozial. Landbau. eV 2016, $28,45-56$.

30. Rovers, A.; Christoph-Schulz, I.; Brümmer, N.; Saggau, D. Die aktuelle Wahrnehmung der Tiergesundheit in der Deutschen Schweinehaltung. J. Austrian Soc. Agric. Econ. 2017, 26, 65-74. [CrossRef]

31. Busch, G.; Gauly, S.; Spiller, A. Wie wirken Bilder aus der modernen Tierhaltung der Landwirtschaft auf Verbraucher? Neue Ansätze aus dem Bereich des Neuromarketings. Schr. Rentenbank 2015, 31, 67-94.

32. Napolitano, F.; Braghieri, A.; Piasentier, E.; Favotto, S.; Naspetti, S.; Zanoli, R. Effect of information about organic production on beef liking and consumer willingness to pay. Food Qual. Prefer. 2010, 21, 207-212. [CrossRef]

33. Kehlbacher, A.; Bennett, R.; Balcombe, K. Measuring the consumer benefits of improving farm animal welfare to inform welfare labelling. Food Policy 2012, 37, 627-633. [CrossRef]

34. Mulder, M.; Zomer, S. Dutch consumers' willingness to pay for broiler welfare. J. Appl. Anim. Welf. Sci. 2017, 20,137-154. [CrossRef] [PubMed]

35. Pouta, E.; Heikkilä, J.; Forsman-Hugg, S.; Isoniemi, M.; Mäkelä, J. Consumer choice of broiler meat: The effects of country of origin and production methods. Food Qual. Prefer. 2010, 21, 539-546. [CrossRef]

36. Dransfield, E.; Ngapo, T.M.; Nielsen, N.A.; Bredahl, L.; Sjödén, P.O.; Magnusson, M.; Campo, M.M.; Nute, G.R. Consumer choice and suggested price for pork as influenced by its appearance, taste and information concerning country of origin and organic pig production. Meat Sci. 2005, 69, 61-70. [CrossRef]

37. Kallas, Z.; Gil, J.M.; Panella-Riera, N.; Blanch, M.; Font-I-Furnols, M.; Chevillon, P.; Roest, K.D.; Tacken, G.; Oliver, M.A. Effect of tasting and information on consumer opinion about pig castration. Meat Sci. 2013, 95, 242-249. [CrossRef]

38. Vanhonacker, F.; Verbeke, W. Buying higher welfare poultry products? Profiling Flemish consumers who do and do not. Poult. Sci. 2009, 88, 2702-2711. [CrossRef]

39. Risius, A.; Hamm, U. The effect of information on beef husbandry systems on consumers' preferences and willingness to pay. Meat Sci. 2017, 124, 9-14. [CrossRef]

40. Liljenstolpe, C. Evaluating animal welfare with choice experiments: An application to Swedish pig production. Agribusiness 2008, 24, 67-84. [CrossRef]

41. Clark, B.; Stewart, G.B.; Panzone, L.A.; Kyriazakis, I.; Frewer, L.J. Citizens, consumers and farm animal welfare: A meta-analysis of willingness-to-pay studies. Food Policy 2017, 68, 112-127. [CrossRef]

42. Simons, J.; Luy, J.; Vierboom, C.; Härlen, I.; Klink-Lehmann, J.; Hartmann, M. Akzeptanz der Nutztierhaltung in Deutschland-Ergebnisse der psychologischen und ethischen Untersuchung von Bestimmungsfaktoren. SocialLab-Nutztierhaltung im spiegel der gesellschaft. J. Consum. Prot. Food Saf. 2018, 13, 145-236. [CrossRef]

43. Vanhonacker, F.; van Poucke, E.; Tuyttens, F.; Verbeke, W. Citizens' views on farm animal welfare and related information provision: Exploratory insights from Flanders, Belgium. J. Agric. Environ. Ethics 2010, 23, 551-569. [CrossRef] 
44. Creswell, J.W.; Clark, V.L.P. Designing and Conducting Mixed Methods Research, 2nd ed.; Sage Publications: Thousand Oaks, CA, USA, 2011.

45. Ritchie, J.; Lewis, J.; McNaughton Nicholls, C.; Ormston, R. Qualitative Research Practice. A Guide for Social Science Students and Researchers, 2nd ed.; Sage Publications: London, UK, 2014.

46. Denscombe, M. Communities of practice: A research paradigm for the mixed methods approach. J. Mix. Methods Res. 2008, 2, 270-283. [CrossRef]

47. Lamnek, S. Gruppendiskussionen. Theorie und Praxis; Beltz: Weinheim, Germany; Basel, Switzerland, 1998.

48. Lamnek, S. Qualitative Sozialforschung; Beltz: Weinheim, Germany; Basel, Switzerland, 2005.

49. Mayring, P. Einführung in Die Qualitative Sozialforschung. Eine Anleitung Zu Qualitativem Denken; Beltz: Weinheim, Germany; Basel, Switzerland, 2002.

50. Halkier, B. Focus groups as social enactments: Integrating interaction and content in the analysis of focus groups data. Qual. Res. 2010, 10, 71-89. [CrossRef]

51. Statistische Ämter des Bundes und der Länder. Agrarstrukturen in Deutschland. Einheit in Vielfalt. Available online: https://www.destatis.de/DE/Themen/Branchen-Unternehmen/Landwirtschaft-ForstwirtschaftFischerei/Landwirtschaftliche-Betriebe/Publikationen/Downloads-Landwirtschaftliche-Betriebe/agrarstrukturenin-deutschland-5411203109004.pdf?_blob=publicationFile (accessed on 30 June 2020).

52. Wolf, C.A.; Tonsor, G.T.; McKendree, M.G.S.; Thomson, D.U.; Swanson, J.C. Public and farmer perceptions of dairy cattle welfare in the United States. J. Dairy Sci. 2016, 99, 5892-5903. [CrossRef]

53. Statistisches Bundesamt. Statistisches Jahrbuch—Deutschland und Internationales. 2019. Available online: https://www.destatis.de/DE/Themen/Querschnitt/Jahrbuch/statistisches-jahrbuch-2019-dl.pdf?_blob= publicationFile (accessed on 30 June 2020).

54. Ventura, B.A.; von Keyserlingk, M.A.G.; Wittman, H.; Weary, D.M. What difference does a visit make? Changes in animal welfare perceptions after interested citizens tour a dairy farm. PLoS ONE 2016, 11, e0154733. [CrossRef] [PubMed]

55. Swinnen, J.F.M.; McCluskey, J.; Francken, N. Food safety, the media, and the information market. Agric. Econ. 2005, 32, 175-188. [CrossRef]

56. Ngapo, T.M.; Dransfield, E.; Martin, J.-F.; Magnusson, M.; Bredahl, L.; Nute, G.R. Consumer perceptions: Pork and pig production. Insights from France, England, Sweden and Denmark. Meat Sci. 2003, 66, 125-134. [CrossRef]

57. Benard, M.; de Cock Buning, T. Exploring the potential of Dutch pig farmers and urban-citizens to learn through frame reflection. J. Agric. Environ. Ethics 2013, 26, 1015-1036. [CrossRef]

58. Kress, K.; Verhaagh, M. The economic impact of German pig carcass pricing systems and risk scenarios for boar taint on the profitability of pork production with immunocastrates and boars. Agriculture 2019, 9, 204. [CrossRef]

59. Hötzel, M.J.; Cardoso, C.S.; Roslindo, A.; von Keyserlingk, M.A.G. Citizens' views on the practices of zero-grazing and cow-calf separation in the dairy industry: Does providing information increase acceptability? J. Dairy Sci. 2017, 100, 4150-4160. [CrossRef]

60. BMEL. Antibiotikaeinsatz in der Nutztierhaltung Sinkt-Resistenzlage Verbessert. Available online: https://www.bmel.de/SharedDocs/Pressemitteilungen/DE/2019/135-antibiotikaminimierungskonzept.html; jsessionid=18A9F582205019ED4FA6807696D69753.internet2852 (accessed on 22 July 2020).

61. Busch, G.; Spiller, A. Warum wir eine Tierschutzsteuer brauchen-Die Bürger-Konsumenten-Lücke. Positionspapier Universität Göttingen, Department für Agrarökonomie und Rurale Entwicklung 2020, Diskussionspapier Nr. 2001. Available online: https://www.uni-goettingen.de/de/document/download/ 7e3ee3661cf99df26d7796608a11d817.pdf/2001_Diskussionsbeitrag_Busch_und_Spiller_2020.pdf (accessed on 30 June 2020).

62. Schröder, M.J.A.; McEachern, M.G. Consumer values conflicts surrounding ethical food purchase decisions: A focus on animal welfare. Int. J. Consum. Stud. 2004, 28, 168-177. [CrossRef]

63. de Bakker, E.; Dagevos, H. Reducing meat consumption in today's consumer society: Questioning the citizen-consumer gap. J. Agric. Environ. Ethics 2012, 25, 877-894. [CrossRef]

64. BMEL. Empfehlungen des Kompetenznetzwerks Nutztierhaltung. Available online: https://www.bmel.de/ SharedDocs/Downloads/DE/_Tiere/Nutztiere/200211-empfehlung-kompetenznetzwerknutztierhaltung.pdf?_blob=publicationFile\&v=1 (accessed on 30 June 2020). 
65. Isermeyer, F. Tierwohl: Freiwilliges Label, Obligatorische Kennzeichnung Oder Staatliche Prämie? Überlegungen Zur langfristigen Ausrichtung der Nutztierstrategie. Available online: https://www.thuenen. de/media/publikationen/thuenen-workingpaper/ThuenenWorkingPaper_124.pdf (accessed on 30 June 2020).

66. Der Spiegel. Corona in the Slaughterhouse-The High Price for Cheap Meat. Available online: https://www.spiegel.de/international/business/corona-in-the-slaughterhouse-the-high-price-of-cheapmeat-a-ad16d0df-c1c8-4f82-93df-573fdc2c8bd6 (accessed on 30 June 2020).

67. DailyNews. Crisis Conversation with Klöckner: Is Our Meat to be Cheap? Available online: https://www. dailynewsen.com/business/Crisis-conversation-with-Klockner-Is-our-meat-to-be-cheap-h17547.html (accessed on 30 June 2020).

(c) (C) 2020 by the authors. Licensee MDPI, Basel, Switzerland. This article is an open access article distributed under the terms and conditions of the Creative Commons Attribution (CC BY) license (http://creativecommons.org/licenses/by/4.0/). 